\title{
Are cutaneous hypersensitivity tests to inhalant allergens a severity marker for vernal keratoconjunctivitis?
}

\author{
Os testes de hipersensibilidade cutânea contra alérgenos inalantes são \\ marcadores de gravidade da ceratoconjuntivite vernal?
}

\author{
Lauro Augusto de Oliveira ${ }^{1}$ \\ Marcia Carvalho Mallozi ${ }^{2}$ \\ Dirceu Sole ${ }^{3}$ \\ Denise de Freitas ${ }^{4}$ \\ Luciene Barbosa de Sousa ${ }^{5}$ \\ Mark J.Mannis ${ }^{6}$
}

\begin{tabular}{l} 
ABSTRACT \\
\hline Purpose: The purpose of this study was to analyze the cutaneous sensi- \\
tivity to a variety of allergens in patients with vernal keratoconjunctivitis \\
(VKC) and to demonstrate the relation between skin response and clinical \\
aspects of the disease. Methods: Twenty patients with vernal kerato- \\
conjunctivitis were randomly chosen from the External Disease and \\
Cornea Sector. They were clinically evaluated, and a score ranging from \\
0 to 20 was applied based on signs and symptoms on ophthalmic \\
examination. All subjects underwent a skin prick test against standardized \\
allergens, such as house dust mites $D$. pteronyssinus, $D$. farinae, and \\
Blomia tropicalis, as well as allergens from cat, dog, fungi and feather. \\
Results: Seventy-five per cent of patients were positive for at least one of \\
the allergens tested. House dust mites were responsible for the majority \\
of the cases ( $75 \%$ ). There was a poor correlation between the clinical \\
score and sensitivity to allergens ( $\mathrm{r}=-0.119$ for fungi; $\mathrm{r}=-0.174$ for \\
dog; $\mathrm{r}=-0.243$ for house dust mites; $\mathrm{r}=-0.090$ for feather). A significant \\
correlation was found only for cat allergen extract ( $\mathrm{r}=-0.510$; $\mathrm{p}=0.024)$. \\
Conclusion: Our study demonstrated poor correlation between cutaneous \\
hypersensitivity tests and clinical findings in patients with vernal \\
keratoconjuntivitis. We concluded that skin response to inhalant aller- \\
gens is not a useful test to identify clinical severity and chronicity of \\
inflammatory process in this disease.
\end{tabular}

Keywords: Hypersensitivity; Conjunctivitis, allergic; Conjunctiva/immunology; Skin tests

\section{INTRODUCTION}

Vernal keratoconjunctivitis (VKC) is a common form of ocular allergy that affects mainly children and teenagers. The diagnosis is based on clinical signs and symptoms including ocular itching, photophobia, mucous discharge, giant papillary reaction in the upper tarsal conjunctiva or limbus, superficial keratitis, and shield ulcers ${ }^{(1)}$. Clinical features can vary from mild to extremely severe, occasionally resulting in significant ocular morbidity. Severe cases of VKC may be chronic and symptomatic, requiring aggressive therapy with corticosteroids. Steroids may predispose patients to infection, increased intraocular pressure, cataract formation, and even blindness ${ }^{(2)}$.

Great effort has been expended to determine the role of cutaneous hypersensitivity tests against inhalant allergens as a complementary tool 
to identify the etiology of ocular allergy, as well as to establish a clinical-laboratory correlation that will predict which patients are predisposed to develop chronic inflammation ${ }^{(3-5)}$.

The role of immunologic investigation has been questioned in patients with VKC. It was reported that a high percentage of patients with ocular allergies showed negative or insignificant cutaneous hypersensitivity test results and serologic levels of total and specific $\operatorname{IgE}^{(6)}$. Other studies demonstrated variable degrees of correlation between those parameters $^{(7-10)}$.

The objective of the present study was to evaluate patients with VKC in the External Diseases and Cornea Service, Department of Ophthalmology, Universidade Federal de São Paulo (UNIFESP/EPM). We analyzed their cutaneous hypersensitivity to inhalant allergens and correlated the testing results with severity of ocular inflammation.

\section{METHODS}

Twenty patients with VKC, regularly seen in the External Diseases and Cornea Service, Department of Ophthalmology, Universidade Federal de São Paulo (UNIFESP/EPM) were randomly invited to volunteer in this prospective study. Informed consent was obtained for all participants from their legally authorized representatives. The study was reviewed and approved by the Research Ethics Committee of the Universidade Federal de São Paulo. Subjects were asked about their symptoms with special attention to age at onset of symptoms, seasonal exacerbation, and personal and family history of allergic diseases, especially atopic disorders such as rhinitis, asthma, food allergies, and allergies caused by medication. All patients were clinically evaluated and received a score based on severity of their ocular inflammation. Primary signs and symptoms of VKC were considered: eyelid edema, conjunctival hyperemia, tearing, photophobia, giant papillary reaction, Trantas' nodules, pannus, punctate epithelial keratitis, and shield ulcers. The score for each of these criteria varied from 0 to 2.5 , with a maximum total score of 20. Ophthalmologic evaluations were performed by the same ophthalmologist (LAO).

Cutaneous hypersensitivity tests were performed using the puncture technique ${ }^{(11)}$ with standardized allergens such as house dust mites D. pteronyssinus, D. farinae, and Blomia tropicalis as well as allergens from cat, dog, fungus and feather. These tests were performed and supervised by the Allergy, Immunology and Rheumatology Sector, Department of Pediatrics, Universidade Federal de São Paulo (UNIFESP/EPM). We used histamine solution $(1 \mathrm{mg} / \mathrm{ml})$ as a positive control, and the vehicle of the same solution as negative control. As exclusion criteria, we considered all situations that might interfere with cutaneous hypersensitivity, such as the use of anti-histamines, tricyclic anti-depressants, and systemic corticosteroids.

Drops of the allergenic extracts and controls were applied to the volar surface of the forearm at $5 \mathrm{~cm}$ intervals. They were then transfixed with special needles to cause mild skin scarification. The reading and measurement of a hardening papule was performed 15 minutes later. The largest diameter and its orthogonal measurement, passing through its centermost point were measured. The presence of at least one positive test, a papule diameter of $\geq 3 \mathrm{~mm}$, characterized the patient as allergic. To evaluate the intensity, we multiplied both diameters, and considered the number of positive tests of each patient.

For statistical analysis, we applied the Mann-Whitney test, Spearman's correlation coefficient, and chi-square test. $\mathrm{P} \leq 0.05$ was considered significant.

\section{RESULTS}

Twenty patients volunteered for this study. The mean age of our patients was 11.3 years, varying from 4 to 19 . The ratio of males to females was 3:1. The age at onset of symptoms varied from 2 to 14 years (mean= 5.5). Seventeen out of 20 $(85 \%)$ subjects reported worsening of the symptoms during the warmest months (Summer in São Paulo - Brazil; December to February), 2/20 (10\%) reported chronic inflammation (itching and red eye) all year, and $1(5 \%)$ during the coldest months (Winter; June to August). Ten of twenty (50\%) reported a family history of allergic disease. Fifteen of twenty $(75 \%)$ reported other personal associated atopic diseases, and 10/20 (50\%) reported both conditions (Table 1).

All subjects reacted positively to histamine solution, and none had any reaction to the negative control. Fifteen patients $(75 \%)$ demonstrated hypersensitivity to at least one of the allergens: $15 / 15$ were sensitive to house dust mites, $9 / 15$ to allergens derived from cat, $6 / 15$ to allergens derived from dog, $2 / 15$ to allergens derived from fungus, and $1 / 15$ to allergens derived from feather (Table 2). Based on the number of positive tests in each patient, we observed: $1 / 15$ was positive to four (4) allergens, $4 / 15$ were positive to three (3), $7 / 15$ were positive to two (2), and $3 / 15$ were positive to only one allergen (Table 2). Clinical evaluation demonstrated that severity varied from 1 to 14 (mean 6.95) (Table 3). The most common clinical features were conjunctival hyperemia, papillary reaction in the upper tarsal conjunctiva, pannus, and punctate epithelial keratitis. The mean severity score for both positive and negative cutaneous hypersensitivity patients did not show statistical significance $(6.9,7.1$ respectively, $\mathrm{p}=0.80$; Mann-Whitney test). Analyzing the relation between the area of the papule induced by puncture of allergens and severity of VKC (Spearman's correlation coefficient) we obtained: $r s=-0,243(p=0,302)$ for house dust mites, $r s=-0,510(p=0,024)$ for cat's allergens, $r s=-0,174$ $(p=0,462)$ for dog's allergens, $r s=-0,119(p=0,615)$ for fungus, and $r s=-0,090(p=0,462)$ for feather. There were no significant changes in this correlation when we excluded patients with negative cutaneous hypersensitivity. Moreover, 


\begin{tabular}{|c|c|c|c|c|c|c|c|}
\hline Patient & Gender & Age & Age at symptom onset & Season of & f worse symptoms & Presence of atopy & Familial history of atopy \\
\hline 1 & $\mathrm{~F}$ & 5 & 3 & & Warm & - & - \\
\hline 2 & M & 17 & 7 & & Warm & - & - \\
\hline 3 & M & 4 & 2 & & Warm & + & - \\
\hline 4 & M & 15 & 9 & & Warm & + & + \\
\hline 5 & M & 11 & 6 & & Warm & + & + \\
\hline 6 & M & 7 & 4 & & Warm & + & + \\
\hline 7 & M & 10 & 4 & & Warm & + & + \\
\hline 8 & M & 10 & 4 & & Warm & + & + \\
\hline 9 & M & 18 & 14 & No & preference & + & - \\
\hline 10 & M & 12 & 6 & No & preference & + & - \\
\hline 11 & M & 11 & 5 & & Warm & - & - \\
\hline 12 & M & 5 & 5 & & Warm & + & + \\
\hline 13 & $\mathrm{~F}$ & 10 & 3 & & Warm & + & - \\
\hline 14 & $\mathrm{~F}$ & 11 & 7 & & Warm & + & + \\
\hline 15 & $\mathrm{~F}$ & 6 & 4 & & Warm & + & - \\
\hline 16 & $\mathrm{~F}$ & 12 & 7 & & Cold & + & + \\
\hline 17 & $\mathrm{M}$ & 17 & 6 & & Warm & + & + \\
\hline 18 & M & 8 & 3 & & Warm & - & - \\
\hline 19 & $\mathrm{M}$ & 17 & 6 & & Warm & + & + \\
\hline 20 & M & 19 & 5 & & Warm & - & - \\
\hline
\end{tabular}

\begin{tabular}{|cccccc|}
\hline \multicolumn{5}{|c|}{ Table 2. Cutaneous immediate hypersensitivity tests with } \\
Patient & Fungus & Cat & Dog & Feather & Mites \\
1 & - & + & + & - & + \\
2 & - & - & - & - & + \\
3 & - & - & - & - & + \\
4 & - & + & - & - & + \\
5 & - & - & - & - & - \\
6 & - & - & + & - & + \\
7 & + & + & - & - & + \\
8 & - & - & + & - & + \\
9 & + & + & + & - & + \\
10 & - & + & + & - & + \\
11 & - & - & - & + & + \\
12 & - & - & - & - & - \\
13 & - & - & - & - & - \\
14 & - & - & - & - & + \\
15 & - & - & - & - & - \\
16 & - & + & + & - & + \\
17 & - & + & - & - & + \\
18 & - & - & - & - & - \\
19 & - & + & - & - & + \\
20 & - & + & - & - & + \\
\hline
\end{tabular}

the relation between the number of positive tests and the clinical severity score was not significant $(\mathrm{rs}=-0.206 ; \mathrm{p}=0.384)$.

\section{DISCUSSION}

The demographic and epidemiological characteristics of patients in the present study are very similar to those reported in other studies on $\mathrm{VKC}^{(2,12)}$.
It is generally believed that $15-20 \%$ of the world population is atopic ${ }^{(13)}$. Atopic profiles are well documented for both personal cases and family histories of allergic diseases. In this study, we verified that $50 \%$ of subjects reported a family history of atopy, and 75\% referred other atopic associated diseases. Allergic rhinitis (70\%) and asthma $(35 \%)$ were the most predominant.

Immediate cutaneous hypersensitivity testing has been an important tool in identifying allergens that can cause allergic diseases ${ }^{(14)}$. However, distinct conditions, such as dermographism $^{(15)}$, anti-histamines and tricyclic anti-depressant administration can interfere in the results. These problems can be obviated by applying tests with positive and negative controls. None of our patients tested negative to histamine or positive to the vehicle of the solution. Seventyfive percent of patients showed susceptibility to inhalant allergens. The same susceptibility to this kind of allergens was described in patients with asthma or rhinitis in our environment ${ }^{(13,16)}$. Some authors found $15 \%$ sensitization in a non-allergic children population against the same inhalant allergens used in this study ${ }^{(16)}$.

VKC is mediated primarily by IgE, with active participation of inflammatory cells in the conjunctiva. Activated eosinophils, soluble mediators, and the expression of adhesion molecules have been recognized as being involved in the ocular surface inflammation and responsible for tissue damage in corneal epithelium ${ }^{(17-20)}$.

The etiologic evaluation of $\mathrm{VKC}$ has demonstrated new findings and new questions about its pathophysiology. Leonardi et al. demonstrated a poor correlation between systemic sensitivity tests (IgE) and ocular sensitivity (IgE from the tear 


\begin{tabular}{|c|c|c|c|c|c|c|}
\hline Patient & Fungus* & Cat $^{*}$ & Dog* & Feather* & Mites* & Clinical score \\
\hline 1 & 0 & 20 & 9 & 0 & 160 & 8.5 \\
\hline 2 & 0 & 0 & 0 & 0 & 44 & 4.5 \\
\hline 3 & 0 & 0 & 0 & 0 & 80 & 7.0 \\
\hline 4 & 0 & 48 & 0 & 0 & 408 & 1.0 \\
\hline 5 & 0 & 0 & 0 & 0 & 0 & 2.0 \\
\hline 6 & 0 & 0 & 9 & 0 & 40 & 12.0 \\
\hline 7 & 9 & 9 & 0 & 0 & 57 & 2.0 \\
\hline 8 & 0 & 0 & 9 & 0 & 34 & 8.5 \\
\hline 9 & 16 & 9 & 12 & 0 & 77 & 5.0 \\
\hline 10 & 0 & 42 & 40 & 0 & 153 & 4.0 \\
\hline 11 & 0 & 0 & 0 & 9 & 112 & 14.0 \\
\hline 12 & 0 & 0 & 0 & 0 & 0 & 8.0 \\
\hline 13 & 0 & 0 & 0 & 0 & 0 & 9.5 \\
\hline 14 & 0 & 0 & 0 & 0 & 9 & 13.5 \\
\hline 15 & 0 & 0 & 0 & 0 & 0 & 8.0 \\
\hline 16 & 0 & 20 & 9 & 0 & 160 & 5.5 \\
\hline 17 & 0 & 12 & 0 & 0 & 265 & 9.0 \\
\hline 18 & 0 & 0 & 0 & 0 & 0 & 8.0 \\
\hline 19 & 0 & 64 & 0 & 0 & 211 & 4.0 \\
\hline 20 & 0 & 12 & 0 & 0 & 83 & 5.0 \\
\hline
\end{tabular}

film), when they observed that $35 \%$ of their patients with VKC presented specific IgE only in tear samples. It suggests that the conjunctiva may be the only target tissue in some patients with allergic disease ${ }^{(6)}$. Some studies demonstrated that $50 \%$ of VKC patients showed negative cutaneous hypersensitivity testing as well as serologic IgE levels. They suggested that an aberration on Th2 lymphocyte line might be evolved in the pathogenesis of $\mathrm{VKC}^{(17)}$. This is reinforced by the finding of $\mathrm{T}$ cell clones, mainly $\mathrm{Th} 2$, in conjunctival tissue biopsies from patients with VKC. So far, by the description of increased in situ hybridization in areas where TCD4+ lymphocytes responsible for the signal to IL-5 were predominant, and associated with high levels of IL-5, instead of IL-2 in the tears from specimens biopsed from VKC patients ${ }^{(21-25)}$.

In the present study, we observed that $75 \%$ of patients were sensitive to at least one inhalant allergen. However, when we compare the clinical severity score of patients with positive and negative hypersensitivity tests, there was no significance. When we analyze the number of allergens to which the patients were sensitive and compared to intensity of cutaneous reaction (papule), there was also no significant correlation. Surprisingly, there was a negative and significant correlation with the allergens derived from cat, suggesting that some cat allergens could be protective: that is, the larger the papule area, the lower the clinical score. However, the present study is based on a small population, and this might not prove true in a larger cohort.

Given the poor correlation between clinical features and immediate cutaneous hypersensitivity, we believe that tests against the inhalant allergens used in this study were not helpful to identify patients with VKC who developed severe and chronic ocular inflammation. Moreover, we do not believe that these cutaneous tests proved to be of benefit in determining therapy against specific allergens, since the ocular inflammation does not correlate with the skin reaction. Perhaps the unique benefit of these tests is to identify the allergens to which the patient is sensitive. Based on that testing, we may be able to advise patients which allergens to avoid. However, testing is not predictive of either intensity or severity of ocular inflammation once the patient is exposed to that specific antigen.

This poor correlation also reinforces the idea that other mechanisms are involved in the pathophysiology of VKC. As mentioned above, the conjunctiva can be an isolated and independent source of inflammation in patients with allergic diseases. It is a disease with a multifactorial pathogenesis, mediated by Th2 lymphocytes, eosinophils, mast cells, and a complex array of cytokines and chemical mediators.

Additional studies with larger numbers and using control subjects without VKC may be helpful to determine the estimated risk relative to severity of cutaneous hypersensitivity.

\section{CONCLUSION}

This study demonstrated poor correlation between immediate cutaneous hypersensitivity testing and the clinical features in patients with vernal keratoconjunctivitis. It demonstrated that cutaneous testing to inhalant allergens was not beneficial in predicting the potential for developing severe and/or chronic ocular surface inflammation. 


\section{RESUMO}

Objetivo: Avaliar o papel da sensibilização cutânea a diferentes aeroalérgenos em pacientes com ceratoconjuntivite vernal e a correlação entre esta e os aspectos clínicos da doença. Métodos: Vinte pacientes do setor de doenças externas e córnea foram aleatoriamente convidados para participar deste estudo. Os pacientes foram avaliados e a eles foi atribuído um escore clínico variando de 0 a 20 de acordo com sinais e sintomas presentes no exame oftalmológico. Todos os pacientes foram submetidos a testes cutâneos de hipersensibilidade imediata contra aeroalérgenos padronizados como os ácaros domiciliares D. pteronyssinus, D. farinae e Blomia tropicalis, assim como também a alérgenos de epitélio de gato, epitélio de cão, mistura de fungos e mistura de penas. Resultados: Setenta e cinco por cento dos pacientes tiveram teste de hipersensibilidade imediata positivo contra pelo menos um dos antígenos testados. Os ácaros domiciliares foram responsáveis pela maioria destes casos $(75 \%)$. Houve uma pobre correlação entre o escore clínico e a hipersensibilidade cutânea aos alérgenos $(\mathrm{r}=-0,119$ para fungos; $\mathrm{r}=-0,174$ para epitélio de cão; $\mathrm{r}=-0,243$ para ácaros domiciliares; $r=-0,090$ para mistura de penas). Houve correlação significativa apenas contra epitélio de gatos $(\mathrm{r}=-0,510$; $\mathrm{p}=0,024)$. Conclusão: $O$ estudo demonstrou uma pobre correlação entre os testes cutâneos de hipersensibilidade imediata e os achados clínicos nos pacientes com ceratoconjuntivite vernal. Os testes cutâneos de hipersensibilidade imediata contra aeroalérgenos não foi parâmetro eficaz na identificação dos casos de maior gravidade e cronicidade de ceratoconjuntivite vernal.

Descritores: Hipersensibilidade; Conjuntivite alérgica; Conjuntiva/imunologia; Testes cutâneos

\section{REFERENCES}

1. Bonini S, Bonini S, Lambiase A, Marchi S, Pasqualetti P, Zuccaro O, et al. Vernal keratoconjunctivitis revisited: a case series of 195 patients with longterm follow-up. Ophthalmology. 2000;107(6):1157-63.

2. Tabbara KF. Ocular complications of vernal keratoconjunctivitis. Can J Ophthalmol. 1999;34(2):88-92.

3. Pastorello EA, Incorvaia C, Ortolani C, Bonini S, Canonica GW, Romagnani $\mathrm{S}$, et al. Studies on the relationship between the level of specific IgE antibodies and the clinical expression of allergy: I. Definition of levels distinguishing patients with symptomatic from patients with asymptomatic allergy to common aeroallergens. J Allergy Clin Immunol. 1995;96(5 Pt 1):580-7.

4. Ownby DR. Clinical significance of IgE. In: Middleton E Jr, Reed CE, Ellis EF, Adkinson NF Jr, Yunginger JW, Busse WW, editors. Allergy: principles and practice. $4^{\text {th }}$ ed. St. Louis: Mosby; 1993. p.1059-76.
5. Norman PS, Lichtenstein LM, Ishizaka K, Comparison of specific IgE antibodies, leukocyte sensitivity by histamine release, direct skin tests, and symptoms in hay fever. In: Goodfriend L, Sehon A, Orange R, editors. Mechanisms in allergy: reagin-mediated hipersensitivity. New York: Marcel Dekker; 1973. p.151-62.

6. Leonardi A, Fregona IA, Gismondi M, Daniotti E, Carniel G, Secchi AG. Correlation between conjunctival provocation test (CPT) and systemic allergometric tests in allergic conjunctivitis. Eye. 1990;4(Pt 5):760-4.

7. Orgel HA, Kemp JP, Meltzer ED, Hamburger RN. Atopy and IgE in a pediatric allergy practice. Ann Allergy.1977;39(3):161-8.

8. Pucci N, Novembre E, Lombardi E, Cianferoni A, Bernardini R, Massai C, et al. Atopy and serum eosinophil cationic protein in 110 white children with vernal keratoconjunctivitis: differences between tarsal and limbal forms. Clin Exp Allergy. 2003;33(3):325-30. Comment in: Clin Exp Allergy. 2003;33(3); 279-81.

9. Soothill JF, Stokes CR, Turner MW, Norman AP, Taylor B. Predisposing factors and the development of reaginic allergy in infancy. Clin Allergy. 1976;6(4):305-19.

10. Foucard T. A follow-up study of children with asthmatoid bronchitis. I. Skin test reactions and IgE antibodies to common allergens. Acta Paediatr Scand. 1973;62(6):633-44.

11. Pepys J. Skin tests for immediate, type, allergic reactions. Proc R Soc Med. 1972;65(3):271-2.

12. Van Asperen PP, Kemp AS, Mellis CM. Skin test reactivity and clinical allergen sensitivity in infancy. J Allergy Clin Immunol. 1984;73(3):381-6.

13. Arruda LK, Rizzo MC, Chapman MD, Fernandez-Caldas E, Baggio D, Platts-Mills TA, et al. Exposure and sensitization to dust mite allergens among asthmatic children in São Paulo, Brazil. Clin Exp Allergy. 1991;21 (4):433-9.

14. JinY, Xu Y, Xue S, Liu H, Zhao J, Xu M. Predicting the development of early skin test sensitization in offspring of parents with asthma. Eur J Clin Invest. 2007;37(6):522-7.

15. Volonakis MK, Tsaptsinos NJ, Kontou-Fili K. The diagnostic value of skinprick tests in dermographic individuals. Allergy Proc. 1991;12(2):103-6.

16. Esteves PC, Rosário Filho NA, Trippia SG, Caleffe LG. Sensibilização atópica em escolares e adultos de Curitiba, Paraná. Rev Bras Alergia Imunopatol. 1999;22(5):156-60.

17. Bonini S, Bonini S. IgE and non IgE mechanisms in ocular allergy. Ann Allergy. 1993;71(3):296-9.

18. Trocme SD, Kephart GM, Allansmith MR, Bourne WM, Gleich GJ. Conjunctival deposition of eosinophil granule major basic protein in vernal keratoconjunctivitis and contact lens-associated giant papillary conjunctivitis. Am J Ophthalmol. 1989;108(1):57-63.

19. Trocme SD, Kephart GM, Bourne WM, Buckley RJ, Gleich GJ. Eosinophil granule major basic protein deposition in corneal ulcers associated with vernal keratoconjunctivitis. Am J Ophthalmol. 1993;115(5):640-3.

20. Bonini S, Tomassini M, Bonini S, Capron M, Balsano F. The eosinophil has a pivotal role in allergic inflammation of the eye. Int Arch Allergy Appl Immunol. 1992;99:354-8.

21. Maggi E, Biswas P, Del Prete G, Parronchi P, Macchia D, Simonelli C, et al. Accumulation of Th2-like helper $\mathrm{T}$ cells in the conjunctiva of patients with vernal conjunctivitis. J Immunol. 1991;146(4):1169-74.

22. Van Leeuwen BH, Martinson ME, Webb GC, Young IG. Molecular organization of the cytokine gene cluster, involving the human IL-3, IL-4, IL-5, and GM-CSF genes, on human chromosome 5. Blood. 1989;73(5): $1142-8$.

23. Trocme SD, Aldave AJ. The eye and the eosinophil. Surv Ophthalmol. 1994; 39(3):241-52. Review.

24. Bonini S, Bonini S, Lambiase A, Magrini L, Rumi C, Del Prete Ge, et al. Vernal keratoconjunctivitis: a model of $5 \mathrm{q}$ cytokine gene cluster disease. Int Arch Allergy Immunol. 1995;107(1-3):95-8.

25. Metz DP, Bacon AS, Holgate S, Lightman SL. Phenotypic characterization of $\mathrm{T}$ cells infiltrating the conjunctiva in chronic allergic eye disease. J Allergy Clin Immunol. 1996;98(3):686-96. 